\title{
Classroom Climate and Student Goal Orientation in English among College Students
}

\author{
Dickey O. Mosqueda \\ Graduate, MAEd in Teaching English, University of Mindanao
}

\begin{abstract}
This study examined the relationship between classroom climate and student goal orientation in English among college students. The study involved 408 freshmen college students from English 101 of UM Panabo Campus. A 40-items questionnaire was administered to the selected respondents. The result of the study showed that the better the condition of the classroom climate, the higher goal orientation of the students in learning English 101. It is suggested that higher goal orientation among students be encouraged despite the desired outcome of this study. Similar studies be conducted to different groups to explore other variables that may have on effect on the goal orientation of students.
\end{abstract}

Keywords: Classroom Climate; Student goal orientation; Descriptive-correlational method; UM Panabo College

\section{INTRODUCTION}

$\mathrm{I}$ n Europe, public elementary school came across problems with regards to goal orientation, students' perceptions of their classroom environments (Tapola \& Niemivirta, 2008). In a different study, Grade 8 African-American and Caucasian students were investigated about their goal orientation and found out that African-American students adopted personal mastery and extrinsic goals significantly more frequently than did Caucasian students, suggesting cultural differences in student goal orientation (Freeman et al. as cited by Mucherah, 2008).

In the Philippines, several studies have been undertaken regarding learning motivation which in this study was used to describe the goal orientation of students. As revealed in those studies, learning motivation was seen to play a vital role in either promoting or hampering intercultural communication and language learning (Lucas et al., 2010). However, it is interesting to note that Filipino students included in those studies were motivated to learn the language due to the very nature of the skills which they found interesting and relevant to them.

However, in the local context Lumaday (2004) showed a negative result on learning motivation among college student. She argued that Davao del Norte State College has been complaining about the observed lack of interest among students in their English classes. This is manifested in the poor goal orientation of students as reflected in the instructor's grading report at the end of every semester.

The researcher found it important to conduct this study, since the same problem is observed to be recurring among students specifically at UM Panabo Campus. Perennial observation in the campus is the explicit inadequacy of the students to present report, oral presentation, inability of a number of students to write good essays inside classroom and towards teachers' course compliance, improper use of oral and written language, passive unassertive behavior in English discourse and deficiencies of basic English communication skills.

\section{Statement of the Problem}

The purpose of the study was to determine the significance of the relationship between classroom climate and student goal orientation in English among students. Specifically, it sought answers to the following questions:

1. What is the condition of classroom climate in English in terms of:

\subsection{Interpersonal relationship}

1.2. Emotional Intonations and structural aspects of teaching style andclassroom organization

1.3. Teacher expectations of students and attitude towards them;

1.4. Level of teacher control

1.5. Disciplinary problems

1.6. The gender and age of the students?

2. What is the level of students goal orientation on terms of:

2.1 Performance goals;

2.2 Learning goals?

3. Is there a significant relationship between classroom climate and student goal orientation?

Hypothesis

The null hypothesis of the study was tested at .05 Level of Significance stated that there is no significant relationship between classroom climate and student goal orientation in English.

\section{THEORETICAL AND CONCEPTUAL FRAMEWORK}

This study is anchored on the goal theory which states that students' goals relate to their classroom climate (Mucherah, 2008). 
Zedan (2010) stressed that classroom climate influences students' behaviors, levels of knowledge, scholastic achievements, motivation, self-image and attitudes towards a certain discipline, the class and school, and schooling and education as a whole. To identify and understand social processes within the classroom, researching the factors enable to know the affect classroom environment, which explain the behavior of the students at both the emotional and cognitive level.

A further study says instructors influence classroom climate by establishing and maintaining the nature of the learning environment in terms of competition, collaboration, and caring (Hirschy\& Wilson, 2002 cited in Johnson, 2006).

As shown in Figure 1, the 1st variable is classroom climate, which includes interpersonal relationships which refer to exist between any two or more persons who interact and fulfill one or more physical or emotional needs; Emotional intonations and relationships which refer to exist between any two or more persons who interact and fulfill one or more physical or emotional needs; Emotional intonations and structural aspects of teaching style and classroom organization; teacher expectations of students and attitudes towards them; level of teacher control; disciplinary problems; the gender and age of the students (Zedan, 2010).

The 2nd variable is student goal orientation, which consist of two major kinds; performance goals and learning goals. Performance goals refer to orientation seeking to maximize favorable evaluations of their ability and minimize negative evaluations of ability. In contrast, with learning goals refer to individuals focus on mastering tasks and increasing competence at different tasks (Mucherah, 2008).

\section{1st Variable}

\section{2nd Variable}

\begin{tabular}{|l|l|}
\hline Classroom Climate & Student Goal Orientation \\
- Interpersonal relationship & $\begin{array}{l}\text { Emotional Intonations and } \\
\text { structural aspects of teaching } \\
\text { style and classroom } \\
\text { organization }\end{array}$ \\
- Teacher expectations of
\end{tabular}

Figure 1: The Conceptual Paradigm Showing the Variables of the Study

\section{METHOD}

Research Design: The researcher made use of descriptivecorrelational method. It is descriptive since it assessed the level of classroom climate and student goal orientation in English among college students. It is correlational in the sense that it determined whether a significant relationship existed between classroom climate and student goal orientations. According to Frankel \& Wallen (1993) as cited by Bermoy (2010) descriptive research includes present conditions concerning the nature of the group or person or class or events which requires procedures of induction, analyses, classification, enumeration and measurement. Similarly, Aquino as cited by Heramil (2007) indicated that the method of conducting a study determine the factors and practices which may assist the researcher to seek accurate description and findings of the status of events.

Research Subjects: The respondents of the study were the first-year students of UM Panabo Campus who were enrolled in English 101 course in the First Semester, 2012-2013.
While the study evaluated the classroom climate and student goal orientation in English among college students, the point of reference in selecting the school was from the total number of first year student with English 101 course in UM Panabo Campus, P.N. Arguelles Street, Barangay San Francisco, Panabo City, Davao del Norte. The researcher utilized the universal sampling in determining the total number of college students enrolled in English 101 in UM Panabo Campus.

The researcher chooses English 101 student as the respondents of the study because it was a required course for all first-year student. A total of 408 students were involved in the study in different programs. Furthermore, students also rated themselves in term of their level of goal orientation.

Therewere 408 or 100 percent first year students served as the subject of the study, 136 were male and 272 were female student. In summary universal sampling used in selecting the number of students as respondents of the study.The study was restricted to classroom climate and student goal orientation in English among college students where the subjects included 
only the teacher handling first year English 101 course in UM Panabo campus.

The classroom climate was delimited to the following aspects: interpersonal relationship, emotional intonations and structural aspects of teaching style and classroom organization, teacher expectation of students and attitudes towards them, level of teacher control, disciplinary problems, the gender and age of the students.

The student goal orientation was also restricted in terms of performance goals and learning goals. The conduct of the study was done during first semester 2012-2013.

Table 1: Distribution of Respondents

\begin{tabular}{|c|c|c|}
\hline Type & $\begin{array}{l}\text { Number of } \\
\text { Respondents }\end{array}$ & $\%$ \\
\hline $\begin{array}{l}\text { Age: } \\
15\end{array}$ & 7 & $1.72 \%$ \\
\hline 16 & 134 & $32.84 \%$ \\
\hline 17 & 113 & $27.70 \%$ \\
\hline 18 & 49 & $12.01 \%$ \\
\hline 19 & 33 & $8.09 \%$ \\
\hline 20 & 16 & $3.92 \%$ \\
\hline 21 & 15 & $3.68 \%$ \\
\hline 22 & 12 & $2.94 \%$ \\
\hline 23 & 9 & $2.21 \%$ \\
\hline 24 & 4 & $0.98 \%$ \\
\hline 25 & 3 & $0.74 \%$ \\
\hline 26 & 2 & $0.49 \%$ \\
\hline 28 & 3 & $0.74 \%$ \\
\hline 30 & 4 & $0.98 \%$ \\
\hline 31 & 1 & $0.25 \%$ \\
\hline 32 & 1 & $0.25 \%$ \\
\hline 40 & 1 & $0.25 \%$ \\
\hline 44 & 1 & $0.25 \%$ \\
\hline Total & 408 & $100 \%$ \\
\hline $\begin{array}{l}\text { Sex: } \\
\text { Male }\end{array}$ & 136 & $33.33 \%$ \\
\hline Female & 272 & $66.67 \%$ \\
\hline Total & 408 & $100 \%$ \\
\hline
\end{tabular}

\section{Research Instrument}

The set of researcher's-made questionnaire was used in gathering the data. The research instrument used in this study was a questionnaire patterned after the book of Bermoy, L. M. (2010), on Teacher Competence and Intrinsic Motivation of Students. The research modified the questionnaire to fit/suit it to the study to determine the classroom climate which deals on interpersonal relationship, emotional intonations and structural aspects of teaching style and classroom organization, teacher expectation of students and attitudes towards them, level of teacher control, disciplinary problems, the gender and age of the students. Set B was adapted from questionnaire of Lepper, et al., (2005) used to determine the student goal orientation which deals on performance goals and learning goals. The test was design for use with respect to basic need satisfaction scale which was used to determine the level of student goal orientation among English students focus on their performance goals and their learning goals.

The improvement of the questionnaire was done in the following manner. First, two sets of questionnaireswere presented to the adviser for comments and suggestions for improvement and refinement. Second, the instrument was checked and approved by the adviser for validation to ensure the content validity before gathering data. Then, comments and suggestions were incorporated in the revised questionnaire by the researcher.

\section{Condition of Classroom Climate}

Interpersonal Relationship:

Table 2 presents the condition of classroom climate in English in terms of interpersonal relationship with means ranging from 3.65 to 4.64 and an overall mean of 4.41 described as Satisfactory. This means that the Condition of classroom climate in terms of interpersonal relationship is Very Good. Table 2 depicted Classroom Climate on the variable Interpersonal Relationship, ranked as Satisfactory were Teacher inspiring students to pursue higher goals, Motivate students to study, Encourage students to express one's thoughts and ideas, Show respect and are comfortable in their dealings and interaction with each other while moderately satisfactory yield Teacher cracking jokes during class discussion to ease boredom and to cheer up students.

The data for interpersonal relationship are arranged from highest mean rating to lowest mean ratings and they are as follows: 4.64 or very satisfactory for Teacher inspiring students to pursue higher goals; 4.63 or very satisfactory for Teacher motivating students to study; 4.61 or very satisfactory for Teacher encouraging students to express one's thoughts and ideas; 4.53 or very satisfactory for Teacher and classmates showing respect and are comfortable in their dealings and interaction with each other; 3.65 or satisfactory for Teacher cracking jokes during class discussion to ease boredom and to cheer up students.

Table 2: Condition of Classroom Climate in English in terms of Interpersonal Relationship

\begin{tabular}{|cl|c|c|c|}
\hline \multicolumn{1}{|c|}{ Item } & $\begin{array}{c}\text { Standard } \\
\text { Deviation }\end{array}$ & Mean & $\begin{array}{c}\text { Descriptive } \\
\text { Equivalent }\end{array}$ \\
\hline 1. & $\begin{array}{l}\text { Teacher and classmates } \\
\text { showing respect and are } \\
\text { comfortable in their } \\
\text { dealings and interaction } \\
\text { with each other }\end{array}$ & 0.656 & 4.53 & $\begin{array}{c}\text { Very } \\
\text { Satisfactory }\end{array}$ \\
\hline 2. & $\begin{array}{l}\text { Teacher cracking jokes } \\
\text { during class discussion to }\end{array}$ & 1.021 & 3.65 & Satisfactory \\
\hline
\end{tabular}




\begin{tabular}{|c|c|c|c|c|}
\hline & $\begin{array}{l}\text { ease boredom and to cheer } \\
\text { up students }\end{array}$ & & & \\
\hline 3. & $\begin{array}{l}\text { Teacher motivating } \\
\text { students to study }\end{array}$ & 0.720 & 4.63 & $\begin{array}{c}\text { Very } \\
\text { Satisfactory }\end{array}$ \\
\hline 4. & $\begin{array}{l}\text { Teacher inspiring students } \\
\text { to pursue higher goals }\end{array}$ & 0.680 & 4.64 & $\begin{array}{c}\text { Very } \\
\text { Satisfactory }\end{array}$ \\
\hline 5. & $\begin{array}{l}\text { Teacher encouraging } \\
\text { students to express one's } \\
\text { thoughts and ideas }\end{array}$ & 0.676 & 4.61 & $\begin{array}{c}\text { Very } \\
\text { Satisfactory }\end{array}$ \\
\hline \multicolumn{2}{|c|}{ Overall Mean } & 0.475 & 4.41 & Satisfactory \\
\hline
\end{tabular}

\section{Emotional Intonations and Structural Aspects of Teaching} Style and Classroom Organization:

Table 3, underscores the condition of classroom climate in terms of emotional intonations and structural aspects of teaching style and classroom organization with mean ranging from 3.39 to 4.38 and an overall mean rating of 4.05 or described as Satisfactory. Depicted in this table is the emotional intonations and structural aspects of teaching style and classroom organization getting attention of students through asking question or opinion about the subject, uses appropriate gestures to emphasize important point or to lead into a new topic, normal voice tone in ordinary conversation during English class discussion, facial expression to convey emotion during English and awareness of intonation that draw attention to it, by using fillers such as: uh huh, ah, um, oh...

The data for emotional intonations and structural aspects of teaching style and classroom organization are arranged from highest to lowest mean ratings and they are as follows: 4.38 or satisfactory for Teacher keeping student's attention by asking question or opinion about the subject; 4.24 or satisfactory for Teacher using appropriate gestures to emphasize important point or to lead into a new topic; 4.22 or satisfactory for Teacher moderating his/her voice in an ordinary conversation during English class discussion; 4.01 or satisfactory forTeacher using facial expression to convey emotion during English class discussion; and 3.39 or moderately satisfactory for Teacher building awareness of intonation that draw attention to it, by using fillers such as: uh huh, ah, um, oh...

Table 3: Condition of Classroom Climate in English in terms of Emotional Intonations and Structural Aspects of Teaching Style and Classroom Organization

\begin{tabular}{|c|c|c|c|}
\hline Item & $\begin{array}{c}\text { Standard } \\
\text { Deviation }\end{array}$ & Mean & $\begin{array}{l}\text { Descriptive } \\
\text { Equivalent }\end{array}$ \\
\hline $\begin{array}{l}\text { 1. Teacher using facial } \\
\text { expression to convey } \\
\text { emotion during English class } \\
\text { discussion }\end{array}$ & 1.007 & 4.01 & Satisfactory \\
\hline $\begin{array}{ll}\text { 2. } & \text { Teacher keeping student's } \\
\text { attention by asking question } \\
\text { or opinion about the subject }\end{array}$ & 0.841 & 4.38 & Satisfactory \\
\hline $\begin{array}{l}\text { 3. Teacher moderating his/her } \\
\text { voice in an ordinary } \\
\text { conversation during English } \\
\text { class discussion }\end{array}$ & 0.848 & 4.22 & Satisfactory \\
\hline $\begin{array}{l}\text { Teacher building awareness } \\
\text { of intonation that draw } \\
\text { attention to it, by using } \\
\text { fillers such as: uh huh, ah, }\end{array}$ & 1.168 & 3.39 & $\begin{array}{l}\text { Moderately } \\
\text { Satisfactory }\end{array}$ \\
\hline
\end{tabular}

\begin{tabular}{|ll|l|l|l|}
\hline um, oh... & & & \\
\hline $5 . \quad \begin{array}{l}\text { Teacher using appropriate } \\
\text { gestures to emphasize } \\
\text { important point or to lead } \\
\text { into a new topic }\end{array}$ & 0.853 & 4.24 & Satisfactory \\
\hline Overall Mean & 0.632 & 4.05 & Satisfactory \\
\hline
\end{tabular}

Teacher Expectations of Students and Attitude towards Them:

Table 4 shows the condition of classroom climate in terms of teacher expectation of students and attitude towards them have mean ranging from 3.77 to 4.19 and an overall mean of 4.07 as Satisfactory. This means that the condition of classroom climate in terms of teacher expectation of students and attitude towards them is very good. Data on this table shows the teachers expectation of students/attitude of students towards them. Satisfactory descriptive results to all areas in this variable; Teacher recognizing that every learner has strength and weaknesses, providing clues, and repeats or rephrases questions during English class discussion, establishing strategies and techniques in order to meet the needs of the students, taking time to wait for student to respond to a given question, praising student's accomplishment in class.

The data for teacher expectation of students and attitude towards them are arranged from highest mean rating to lowest mean ratings and they are as follows: 4.19 or satisfactory for Teacher recognizing that every learner has strength and weaknesses; 4.18 or satisfactory for Teacher providing clues, and repeats or rephrases questions during English class discussion; 4.10 or satisfactory for Teacher establishing strategies and techniques in order to meet the needs of the students; 4.10 or satisfactory for Teacher taking time to wait forstudent to respond to a given question; 3.77 or satisfactory for Teacher praising student's accomplishment in class.

Table 4: Condition of Classroom Climate in English in terms of Teacher Expectations of Students and Attitude towards Them

\begin{tabular}{|c|c|c|c|}
\hline \multicolumn{1}{|c|}{ Item } & $\begin{array}{c}\text { Standard } \\
\text { Deviation }\end{array}$ & Mean & $\begin{array}{l}\text { Descriptive } \\
\text { Equivalent }\end{array}$ \\
\hline $1 . \quad \begin{array}{l}\text { Teacher praising student's } \\
\text { accomplishment in class }\end{array}$ & 1.103 & 3.77 & Satisfactory \\
\hline $2 . \quad \begin{array}{l}\text { Teacher establishing } \\
\text { strategies and techniques in } \\
\text { order to meet the needs of the } \\
\text { students }\end{array}$ & 0.875 & 4.10 & Satisfactory \\
\hline $3 . \quad \begin{array}{l}\text { Teacher providing clues, and } \\
\text { repeats or rephrases questions } \\
\text { during English class } \\
\text { discussion }\end{array}$ & 0.880 & 4.18 & Satisfactory \\
\hline $4 . \quad \begin{array}{l}\text { Teacher taking time to wait } \\
\text { for student to respond to a } \\
\text { given question }\end{array}$ & 0.899 & 4.10 & Satisfactory \\
\hline $5 . \quad \begin{array}{l}\text { Teacher recognizing that } \\
\text { every learner has strength and } \\
\text { weaknesses }\end{array}$ & 0.954 & 4.19 & Satisfactory \\
\hline \multicolumn{1}{c}{ Overall Mean } & 0.643 & 4.07 & Satisfactory \\
\hline
\end{tabular}




\section{Level of Teacher Control}

Table 5 exhibits the condition of classroom climate in term of level of teacher control have mean ranging from 3.32 to 4.49 and an overall mean 3.99 as Satisfactory. This means that the condition of classroom climate in terms of level of teacher control is very good. Result show presents the level of teacher control showing satisfactory descriptions on teacher maintains discipline, morale and promote group activities from students, monitoring student progress using appropriate assessment or evaluation techniques, showing interest in students' problem and needs and helping meet them while moderately satisfactory to informing student progress to the parents.

The data for level of control are arranged from highest mean rating to lowest mean ratings and they are as follows: 4.49 or satisfactory for Teacher maintaining discipline, morale and promote group activities from students; 4.39 or satisfactory for Teacher maintaining a safe and orderly classroom that is free from interruption/disturbance; 4.08 or satisfactory for Teacher monitoring student progress using appropriate assessment or evaluation techniques; 3.66 or satisfactory for Teacher showing interest in students' problem and needs and helping meet them; and 3.32 or moderately satisfactory for Teacher informing student progress to the parents.

Table 5: Condition of Classroom Climate in English in terms of Level of Teacher Control

\begin{tabular}{|cl|c|c|c|}
\hline \multicolumn{1}{|c|}{ Item } & $\begin{array}{c}\text { Standard } \\
\text { Deviation }\end{array}$ & Mean & $\begin{array}{l}\text { Descriptive } \\
\text { Equivalent }\end{array}$ \\
\hline 1. & 0.852 & 4.39 & Satisfactory \\
$\begin{array}{l}\text { Teacher maintaining a safe } \\
\text { and orderly classroom that is } \\
\text { free from } \\
\text { interruption/disturbance }\end{array}$ & 0.743 & 4.49 & Satisfactory \\
\hline 2. & $\begin{array}{l}\text { Teacher maintaining } \\
\text { discipline, morale and } \\
\text { promote group activities from } \\
\text { students }\end{array}$ & 0.855 & 4.08 & Satisfactory \\
\hline 3. & $\begin{array}{l}\text { Teacher monitoring student } \\
\text { progress using appropriate } \\
\text { assessment or evaluation } \\
\text { techniques }\end{array}$ & 1.270 & 3.32 & $\begin{array}{l}\text { Moderately } \\
\text { Satisfactory }\end{array}$ \\
\hline $4 . \quad \begin{array}{l}\text { Teacher informing student } \\
\text { progress to the parents }\end{array}$ & 1.104 & 3.66 & Satisfactory \\
\hline $5 . \quad \begin{array}{l}\text { Teacher showing interest in } \\
\text { students' problem and needs } \\
\text { and helping meet them }\end{array}$ & 0.630 & 3.99 & Satisfactory \\
\hline \multicolumn{2}{|c|}{ Overall Mean } & &
\end{tabular}

\section{Disciplinary Problems:}

Table 6 presented the condition of classroom climate in terms of disciplinary problems have means ranges from 2.46 to 4.14 with overall mean of 3.48 or described as moderately satisfactory. This meansthat condition of classroom climate in terms of disciplinary problems is good. Data shows the variable Classroom climate - Disciplinary Problems. Teacher treating students fairly regardless of their tribes/differences, and Teacher providing time for student consultation depicted satisfactory responses; when Teacher monitoring student's work personally, it resulted to moderate response consequently, putting unsatisfactory to teacher visiting students homes when students have problems or being absent from school/classes.

The data for Disciplinary problems are arranged from highest mean rating to lowest mean ratings and they are as follows: 4.14 or satisfactory for Teacher treating students fairly regardless of their tribes/differences; 3.87 or satisfactory for Teacher showing interest in the problems and difficulties encountered by students; 3.62 or satisfactory for Teacher providing time for student consultation; 3.31 or moderately satisfactory for Teacher monitoring student's work personally; 2.46 or unsatisfactory for Teacher visiting students in their homes especially those students with absences or problems.

Table 6: Status of Classroom Climate in English in terms of Disciplinary Problems

\begin{tabular}{|cl|c|c|c|}
\hline \multicolumn{1}{|c|}{ Item } & $\begin{array}{c}\text { Standard } \\
\text { Deviation }\end{array}$ & Mean & $\begin{array}{c}\text { Descriptive } \\
\text { Equivalent }\end{array}$ \\
\hline 1. & $\begin{array}{l}\text { Teacher visiting students in } \\
\text { their homes especially those } \\
\text { students with absences or } \\
\text { problems }\end{array}$ & 1.239 & 2.46 & Unsatisfactory \\
\hline 2. & $\begin{array}{l}\text { Teacher monitoring } \\
\text { student's work personally }\end{array}$ & 1.181 & 3.31 & $\begin{array}{c}\text { Moderately } \\
\text { Satisfactory }\end{array}$ \\
\hline 3. & $\begin{array}{l}\text { Teacher providing time for } \\
\text { student consultation }\end{array}$ & 1.075 & 3.62 & Satisfactory \\
\hline 4. & $\begin{array}{l}\text { Teacher treating students } \\
\text { fairly regardless of their } \\
\text { tribes/differences }\end{array}$ & 1.047 & 4.14 & Satisfactory \\
\hline 5. & $\begin{array}{l}\text { Teacher showing interest in } \\
\text { the problems and } \\
\text { difficulties encountered by } \\
\text { students }\end{array}$ & 1.031 & 3.87 & Satisfactory \\
\hline & \multicolumn{1}{c|}{ Overall Mean } & 0.769 & 3.48 & $\begin{array}{c}\text { Moderately } \\
\text { Satisfactory }\end{array}$ \\
\hline
\end{tabular}

\section{The Gender and Age of the Students:}

Table 7 presented the condition of classroom climate in terms of the gender and age of the students have means ranges from 3.82 to 4.55 with overall mean of 4.33 or described as satisfactory. This means that the condition of classroom climate in terms of the gender and age of the students is very good. Data showed Teachers treat boys and girls equally, student have a good relationship regardless of age gap, older or younger compared to them, Teachers equally motivate boys and girls, teachers alsoequitably relate towards boys and girl's questions and students are more comfortable to ask questions to younger classmates than older ones.

The data for the gender and age of the students are arranged from highest mean rating to lowest mean ratings and they are as follows: 4.55 or satisfactory for Teacher giving equal treatment to boys as well as girls in English class; 4.52 or very satisfactory for Students maintaining a good relationship with older or younger classmates in English class; 4.42 or satisfactory for Boys and girls being both motivated to study in English; 4.33 or satisfactory for Teacher relating 
equally/equitably to boys' and girls' questions in English class; and 3.83 or satisfactory for Students feeling comfortable to ask question to younger classmates during English class.

Table 7: Condition of Classroom Climate in English in terms of Gender and Age of Students

\begin{tabular}{|c|c|c|c|}
\hline Item & $\begin{array}{l}\text { Standard } \\
\text { Deviation }\end{array}$ & Mean & $\begin{array}{l}\text { Descriptive } \\
\text { Equivalent }\end{array}$ \\
\hline $\begin{array}{l}\text { 1. Teacher giving equal } \\
\text { treatment to boys as well } \\
\text { as girls in English class }\end{array}$ & 0.944 & 4.55 & $\begin{array}{c}\text { Very } \\
\text { Satisfactory }\end{array}$ \\
\hline $\begin{array}{ll}\text { 2. } & \text { Students feeling } \\
\text { comfortable to ask } \\
\text { question to younger } \\
\text { classmates during English } \\
\text { class }\end{array}$ & 1.153 & 3.83 & Satisfactory \\
\hline $\begin{array}{ll}\text { 3. } & \text { Teacher relating } \\
\text { equally/equitably to boys' } \\
\text { and girls' questions in } \\
\text { English class }\end{array}$ & 0.824 & 4.33 & Satisfactory \\
\hline $\begin{array}{l}\text { 4. Students maintaining a } \\
\text { good relationship with } \\
\text { older or younger } \\
\text { classmates in English } \\
\text { class }\end{array}$ & 0.769 & 4.52 & $\begin{array}{c}\text { Very } \\
\text { Satisfactory }\end{array}$ \\
\hline $\begin{array}{l}\text { 5. Boys and girls being both } \\
\text { motivated to study in } \\
\text { English } \\
\end{array}$ & 0.793 & 4.42 & Satisfactory \\
\hline Overall Mean & 0.605 & 4.33 & Satisfactory \\
\hline
\end{tabular}

\section{SUMMARY}

Presented in Table 8 is the condition of classroom climate with mean ranging from 3.48 to 4.41 and an overall mean rating of 4.05 or described as satisfactory. This means that the condition of classroom climate in terms is very good. Data presents the summary of the student condition of climate as putting Interpersonal Relationship, Gender and Age of the Students, Teacher Expectations of Students and Attitude Towards Them, Emotional Intonations and Structural Aspects of Teaching Style and Classroom Organization as Level of Teacher Control as satisfactory while Disciplinary Problems as Moderately Satisfactory.

The indicators for classroom climate are classified from highest mean rating to lowest mean ratings and they are as follows: 4.41 or satisfactory forInterpersonal Relationship; 4.33 or satisfactory for The Gender and Age of the Students; 4.07 or satisfactory for Teacher Expectations of Students and Attitude Towards Them; 4.05 or satisfactory for Emotional Intonations and Structural Aspects of Teaching Style and Classroom Organization; 3.99 or satisfactory for Level of Teacher Control; of 3.48 or Moderately Satisfactory for Disciplinary Problems.

Table 8: Summary of the Condition of Classroom Climate in English

\begin{tabular}{|c|c|c|c|}
\hline Item & $\begin{array}{c}\text { Standard } \\
\text { Deviation }\end{array}$ & Mean & $\begin{array}{c}\text { Descriptive } \\
\text { Equivalent }\end{array}$ \\
\hline Interpersonal Relationship & 0.475 & 4.41 & Satisfactory \\
\hline $\begin{array}{c}\text { Emotional Intonations and } \\
\text { Structural Aspects of Teaching }\end{array}$ & 0.632 & 4.05 & Satisfactory \\
\hline
\end{tabular}

\begin{tabular}{|c|c|c|c|}
\hline Style and Classroom Organization & & & \\
\hline $\begin{array}{c}\text { Teacher Expectations of Students } \\
\text { and Attitude Towards Them }\end{array}$ & 0.643 & 4.07 & Satisfactory \\
\hline Level of Teacher Control & 0.630 & 3.99 & Satisfactory \\
\hline Disciplinary Problems & 0.769 & 3.48 & $\begin{array}{c}\text { Moderately } \\
\text { Satisfactory }\end{array}$ \\
\hline $\begin{array}{c}\text { The Gender and Age } \\
\text { of the Students }\end{array}$ & 0.605 & 4.33 & Satisfactory \\
\hline Overall Mean & 0.454 & 4.05 & Satisfactory \\
\hline
\end{tabular}

\section{Level of Student Goal Orientation}

\section{Performance Goals:}

Table 9 exhibits the level of student goal orientation in term of performance goals with mean ranging from 3.45 to 3.70 and an overall mean 3.57 or described as high. This means that the level of student goal orientation in terms of performance goals is evident in most class activities they participated. Data show the Student Goal Orientation on Performance Goals. Presented in the above data Students are good in communication skills, able to excel in any activities during English class, better when teacher initiates group discussion in English class able in both oral and written communication as High while Moderate to surpass others in terms of writing English articles.

The data for performance goals are arranged from highest mean rating to lowest mean ratings and they are as follows: 3.70 or high for Being good in communication skills; 3.62 or high for Being able to excel in many activities during English class; 3.55 or high for Being better when teacher initiates group discussion in English class; 3.53 or high for Being able to be good both oral and written communication; obtained a score of 3.45 or moderate for Being able to surpass others in terms of writing English articles.

Table 9: Level of Students Goal Orientation in terms of Performance Goals

\begin{tabular}{|cl|c|c|c|}
\hline \multicolumn{1}{|c|}{ Item } & $\begin{array}{c}\text { Standard } \\
\text { Deviatio } \\
\mathrm{n}\end{array}$ & Mean & $\begin{array}{c}\text { Descriptive } \\
\text { Equivalent }\end{array}$ \\
\hline 1. & $\begin{array}{l}\text { Being good in } \\
\text { communication skills }\end{array}$ & 0.803 & 3.70 & High \\
\hline 2. & $\begin{array}{l}\text { Being able to surpass } \\
\text { others in terms of writing } \\
\text { English articles }\end{array}$ & 0.862 & 3.45 & Moderate \\
\hline $3 . \quad \begin{array}{l}\text { Being better when teacher } \\
\text { initiates group discussion } \\
\text { in English class }\end{array}$ & 1.000 & 3.55 & High \\
\hline $4 . \quad \begin{array}{l}\text { Being able to excel in } \\
\text { many activities during } \\
\text { English class }\end{array}$ & 0.923 & 3.62 & High \\
\hline $5 . \quad \begin{array}{l}\text { Being able to be good both } \\
\text { oral and written } \\
\text { communication }\end{array}$ & 0.939 & 3.53 & High \\
\hline & $\quad$ Overall Mean & 0.701 & 3.57 & High \\
\hline
\end{tabular}




\section{Learning Goals:}

Table 10 exposed the level of student goal orientation in terms of learning goals with mean ranging from 3.62 to 4.16 and an overall mean of 3.80 described as High. This means that the level of student goal orientation in terms of learning goals is evident in most class activities they participated. Table 10 shows Student Goal Orientation on Learning Goals. Table implies students being trained by English teachers to use the language properly both oral/written communication as High so learning to be competent in English grammar and structure, able to do easily the task of reporting in English class and Moderate in Teachers giving task to give presentation or reports.

The data for learning goals are arranged from highest mean rating to lowest mean ratings and they are as follows: 4.16 or high for Being trained by English teacher to use the language properly may it be oral or written; 4.04 or high for Learning to speak and write well in English class; 3.91 or high for Learning to be competent in English grammar and structure through writing good essays in English class; 3.62 or high for Being able to do easily the task of reporting in English class; 3.27 or moderate for Being always tasked by English teacher to give presentation or reports whenever the class has a group discussion.

Table 10: Level of Students Goal Orientation in terms of Learning Goals

\begin{tabular}{|c|c|c|c|}
\hline Item & $\begin{array}{c}\text { Standard } \\
\text { Deviation }\end{array}$ & Mean & $\begin{array}{c}\text { Descriptive } \\
\text { Equivalent }\end{array}$ \\
\hline $\begin{array}{c}\text { Learning to speak and write well } \\
\text { in English class }\end{array}$ & 0.898 & 4.04 & High \\
\hline $\begin{array}{c}\text { Being able to do easily the task of } \\
\text { reporting in English class }\end{array}$ & 0.955 & 3.62 & High \\
\hline $\begin{array}{c}\text { Being trained by English teacher } \\
\text { to use the language properly may } \\
\text { it be oral or written }\end{array}$ & 0.938 & 4.16 & High \\
\hline $\begin{array}{c}\text { Learning to be competent in } \\
\text { English grammar and structure } \\
\text { through writing good essays in } \\
\text { English class }\end{array}$ & 0.956 & 3.91 & High \\
\hline $\begin{array}{c}\text { Being always tasked by English } \\
\text { teacher to give presentation or } \\
\text { reports whenever the class has a } \\
\text { group discussion }\end{array}$ & 1.157 & 3.27 & Moderate \\
\hline Overall Mean & 0.725 & 3.80 & High \\
\hline
\end{tabular}

\section{Summary:}

Table 11 reveals the summary of the level of student goal orientation with mean ranging from 3.57 to 3.80 and an overall mean 3.68 or described as High. This means that the level of student goal orientation is evident in most class activities they participated. These signify that students are motivated to pursue their goals on their English 101 subject also its shows that students are interested to learn the subject matter.

The indicators for student goal orientation are arranged from highest mean rating to lowest mean ratings and they are as follows: 3.57 or high for Performance Goals; and 3.80 or high for Learning Goals.

Table 11: Summary of the Level of Students Goal Orientation

\begin{tabular}{|c|c|c|c|}
\hline Item & $\begin{array}{c}\text { Standard } \\
\text { Deviation }\end{array}$ & Mean & $\begin{array}{c}\text { Descriptive } \\
\text { Equivalent }\end{array}$ \\
\hline Performance Goals & 0.701 & 3.57 & High \\
\hline Learning Goals & 0.725 & 3.80 & High \\
\hline Overall Mean & 0.653 & 3.68 & High \\
\hline
\end{tabular}

Significance of the Relationship between Classroom Climate and Student Goal Orientation

Table 12 shows the significant relationship between classroom climate and student goal orientation in English 101 first year student. The overall mean of the significant relationship between classroom climate and student goal orientation has computed r-value of 0.462 and probability value of 0.00 ; the disciplinary problem computed overall $\mathrm{r}$-value of 0.479 and has overall probability value of 0.00 which is lesser than 0.05 ; the gender and age of the student computed overall $r$-value of 0.359 and has overall probability of 0.00 which is lesser that 0.05 ; level of teacher control computer the overall $r$-value of 0.348 and has overall probability of 0.00 which is lesser than 0.05 ; teacher expectations of students and attitude towards them computer the overall $\mathrm{r}$-value of 0.259 and has overall probability of 0.00 which is lesser than 0.05 ; Emotional Intonations and Structural Aspects of Teaching Style and Classroom Organization computer the overall r-value of 0.259 and has overall probability of 0.00 which is lesser than 0.05 ; and for interpersonal relationship computer overall $r$-value of 0.235 and has overall probability of 0.00 which is lesser than 0.05 . This means that the relationship between classroom climate and student goal orientation in English is significant since the r-value of 0.462 has probability value of 0.00 which is lesser than 0.05 a significant level set in this study.

The results and findings of the study support the theory where the study is anchored in the theory of Mucherah (2008), which state that, students' goals relate to their classroom climate.

\section{CONCLUSIONS}

Based on the findings of the study, the following concluded that the better the condition of the classroom climate, the higher the goal orientation of the students on the English, since the computed $r$-value ranges from 0.235 to 0.479 with overall computed $r$-value of 0.462 very much higher than the corresponding probability value of 0.113 at $\alpha=0.05$ level of significance. The result articulated that the null hypothesis of the study is rejected. Data showed that there is a significant relationship between classroom climate and student goal orientation when measured through interpersonal relationship described as satisfactory; emotional intonations and structural aspects of teaching style and classroom organization described as satisfactory; teacher expectations of students and attitude towards them described as satisfactory; level of teacher 
control described as satisfactory; disciplinary problems described as moderately satisfactory; gender and age of the students described as satisfactory: and performance goals described as high and learning goals described as high.

\section{RECOMMENDATIONS}

Based on the findings and conclusions, the following recommendations are drawn:

1. Future research and studies on goal orientation on various groups, such as per program, particularly education, and those specializing in English course for UM Panabo as an offered program with license tests, are urged for school directors.

2. For program leaders to design a strategy that will improve that can serve as a guide to every program in terms of goal orientation, especially where students are weak, so that the student can be motivated to learn the English course.

3. Teachers can employ tactics, interventions, and multimedia to encourage students to engage in audiovisual activity and other technology that meets their English competency needs.

4. Students should develop and practice the habit of paying greater attention and exerting more effort in their regular activities by incorporating the English course into their daily routine. Regardless of the study's desired outcome, goal orientation among English students is promoted. In the realm of conditions and normal settings, evaluating classroom management and strategies for delivering instructions is also recommended.

\section{REFERENCES}

[1] Adelman, H.S. \& Taylor, L. (2005). Classroom Climate. Retrieved on January 28, 2012. From http://smhp.psych.ucla.edu/publications/46\%20classroom\%20clim ate.pdf

[2] Aquino, Y. B. (2010). Interpersonal behavior of teachers and wellbeing of public secondary students. University of Mindanao, Davao City.

[3] Bangkas, F. D., (2003). The teaching concerns of beginning teachers and their teaching performance. University of Mindanao, Davao City.

[4] Bermoy, L. M. (2010) Teacher competence and intrinsic motivation of students. University of Mindanao, Davao City.

[5] Brackett, M. A., Reyes, M. R., Rivers, S. E., Elbertson, N. A., \& Salovey, P. (2011). Classroom emotional climate, teacher affiliation, and student conduct. The Journal of Classroom Interaction, 46(1), 27-36. Retrieved from http://search.proquest.com/docview/915267885?accountid=31259

[6] Callahan, C. M. (2006). An investigation into the gender and age differences in the social coping of academically advanced students. Journal of Advanced Academics, 18(1), 60-80,155-156. Retrieved from http://search.proquest.com/docview/222747897?accountid=31259

[7] Campbell, D. E. (2008). Voice in the classroom: How an open classroom climate fosters political engagement among adolescents. Political Behavior, 30(4), 437-454. doi:10.1007/s11109-008-9063-z
[8] David, M. M. (2009). Achievement goals in mathematics. Retrieved on February 4, 2012. From http://pemea.club.officelive.com/Documents/A4_V2_AH.pdf

[9] Gonzales, R. (2010). Motivational orientation in foreign language learning: the case study of filipino foreign language learner. Retrieved on February 12, 2012. From http://www.tesoljournal.com/PDF/A1_V3 TESOL.pdf

[10] Heramil, N. B. (2007). Teacher attributes and instructional effectives of the Teresian Daughters of Mary, Managed Schools: Basis for an intervention program. Dissertation. University of Mindanao.

[11] Hewson, P.W. (2009). Analysis and use of a task for indentifying conceptions of teaching science. Journal of Education for Teaching, 15, 191-209.

[12] Hsieh, P., Cho, Y., Liu, M., Schallert, D. L. (2008). Middle school focus: Examining the interplay between middle school students achievement goals and self-efficacy in a technology-enhancement learning environment. Retrieved on February 4, 2012. From http://alienrescue.edb.utexas.edu/researchpapers/GOSE_Final.pdf

[13] Inato, R. L., (2005). Teacher empowerment and classroom management in buhangin district. University of Mindanao, Davao City.

[14] Integrating New Technology Into the Method of Education (2001). Classroom Management. Retrieved on February 24, 2012. From http://www.intime.uni.edu/model/teacher/teac3summary.html

[15] Joaquin, N., Ganaden, M. \& Ibe, M. (2008). Goal modification, learning styles, and achievement in mathematics. Retrieved on $\begin{array}{llll}\text { February } & 4, & 2012 . & \text { From }\end{array}$ http://journals.upd.edu.ph/index.php/edq/article/viewFile/1567/15 16

[16] Johnson, G. M. (2006). Perception of classroom climate, use of WebCT, and academic achievement. Journal of Computing in Higher Education, 17(2), 25-46. doi:10.1007/BF03032697

[17] Lazaratou, H., Dikeos, D. G., Anagnostopoulos, D. C., \&Soldatos, C. R. (2010). Depressive symptomatology in high school students: The role of age, gender and academic pressure. Community Mental Health Journal, 46(3), 289-95. doi:10.1007/s10597-0109296-2

[18] Lepper, M. R., Iyengar, S. S. \& Corpus, J. H. (2005). Intrinsic and Extrinsic Motivational Orientations in the Classroom: Age Differences and Academic Correlates. Retrieved on February 29, $2012 . \quad$ From http://www.columbia.edu/ ss957/articles/Lepper_Corpus_Iyengar. pdf

[19] Li, A., Fang, Q., \& Dang, J. (2011). Emotional intonation in a tone language: experimental evidence from Chinese. Retrieved on January 15, 2012.From http://www.icphs2011.hk/resources/OnlineProceedings/RegularSe ssion/Li,\%20Aijun/Li,\%20Aijun.pdf

[20] Lucas, R., Pulido, D., Miraflores, E., Ignacio, A., Tacay, M. \& Lao, J. (2010). A study on the intrinsic motivation factors in second language learning among selected freshman students. Retrieved on February 12, 2012. From http://www.philippine-esljournal.com/V4_A1.pdf

[21] Lumaday, E. J. (2004). Teaching practices of English instructors in developing communicative competence and achievement motivation of students. University of Mindanao, Davao City.

[22] Magno, C. \&Lajom, J. A., (2008). A cross-sectional study of high school and college adolescents in their use of self-regulation, selfefficacy, metacognition, and achievement goals. Retrieved on August 3, 2012. From http://www.scribd.com/doc/7811252/ACrossSectional-Study-of-High-school-and-College-Adolescentsin-their-use-of-Selfregulation-Selfefficacy-Metacognition-andAchievement-Goals

[23] Martin, P. \& Thomas, G., (2000). Interpersonal relationships as a metaphor for human-nature relationships. Australian Journal of Outdoor Education, 5(1), 39-46. Retrieved from http://search.proquest.com/docview/232847391 ?accountid=31259

[24] Mello, Z. R., \& Worrell, F. C. (2006). The relationship of time perspective to age, gender, and academic achievement among 
academically talented adolescents. Journal for the Education of the Gifted, 29(3), 271-289,363-364. Retrieved from http://search.proquest.com/docview/222274182?accountid=31259

[25] Miller, A. \& Cunningham, K. (2006). Classroom environment. Retrieved on January 21, 2012. From http://www.education.com/reference/article/classroomenvironment/

[26] Mucherah, W. (2008). Classroom climate and students goal structures in high-school biology classrooms in kenya. Learning Environments Research, 11(1), 63-81. doi:10.1007/s10984-0079036-x

[27] Noor-Azniza, I., Malek, T. J., Ibrahim, Y. S., \& Farid, T. M. (2011). Moderating effect of gender and age on the relationship between emotional intelligence with social and academic adjustment among first year university students. Internationa Journal of Psychological Studies, 3(1), 78-89. Retrieved from http://search.proquest.com/docview/877024564?accountid=31259

[28] Ocay, R. B., (2003). Teachers' self-efficacy and pupils' achievement. University of Mindanao, Davao City

[29] Razo, E., (2009). Development and intellectual virtues of teachers University of Mindanao, Davao City

[30] Reilly, P. (2007).Performance goals vs learning goals: are we learning or looking good? Retrieved on February 4, 2012. From http://preilly.wordpress.com/2007/12/19/performance-goals-vslearning-goals-are-we-learning-or-looking-good/

[31] Robles, J. G., (2007). Classroom Management skills of teachers and classroom interaction of high school students. University of Mindanao, Davao City.

[32] Roebken, H. (2007). Multiple goals, satisfaction, and achievement in university undergraduate education: A Student Experience in the Research University (SERU) Project Research Paper. Retrieved on February 2, 2012. From http://cshe.berkeley.edu/publications/docs/ROP.Roebken.2.07.pdf

[33] Silva, D. L., Tadeo, M. C., Delos Reyes, C. R. V. \&Dadigan, R. M. (2006). Factors associated with non-performing filipino students in mathematics: a vision of student's cognitive and behavior management. Retrieved on February 12, 2012. From http://math.usm.my/research/OnlineProc/ED12.pdf

[34] Su, A. \& Wang, Z. (2007). Affective intonation-modeling for mandarin based on pca. Retrieved on February 15, 2012. From http://www.aclclp.org.tw/clclp/v12n1/v12n1a3.pdf

[35] Svinicki, M. D. (2006). Student goal orientation, motivation, and learning. The Idea Center. Retrieved on February 3, 2012. From http://www.education.com/reference/article/Ref_Student_Goal/

[36] Tapola, A. \& Niemivirta, M., (2008).The role of achievement goal orientations in students' perceptions of and preferences for classroom environment. British Journal of Educational Psychology (2008), 78, 291-312

[37] The School Of Graduate Studies and Continuing Education (2005). Creating a Safe and Engaging Classroom Climate. Retrieve on January 23, 2012. From http://www.uww.edu/learn/diversity/safeclassroom.php

[38] Walter, S. M., Lambie, G. W., \& Ngazimbi, E. E. (2008). A choice theory counseling group succeeds with middle school students who displayed disciplinary problems. Middle School Journal, 40(2), 4-12. Retrieved from http://search.proquest.com/docview/217441116?accountid=31259

[39] Weber, M. J. (2007) .The Importance of Interpersonal Relationships. Retrieved on January 14, 2012. From http://cnx.org/content/m14428/latest/

[40] Wittink, D. R. and L.R. Bayer (1994). "The Measurement Imperative" Marketing Research, Vol. 6(4), 1994, 14.

[41] Zedan, R. (2010). New dimensions in the classroom climate. Learning Environments Research, 13(1), 75-88. doi:10.1007/s10984-009-9068-5

[42] Zhan, S. (2004). Interpersonal Relationship between Teachers and Students: An Intercultural Study on Chinese and Australian Universities. Retrieved on January 14, 2012. From http://www.aare.edu.au/04pap/zha04171.pdf http://en.scientificcommons.org/39004640 